GRASAS Y ACEITES 68 (4)

October-December 2017, e227

ISSN-L: 0017-3495

doi: http://dx.doi.org/10.3989/gya.0444171

\title{
Effect of pretreatment on the proximate composition, physicochemical characteristics and stability of Moringa peregrina oil
}

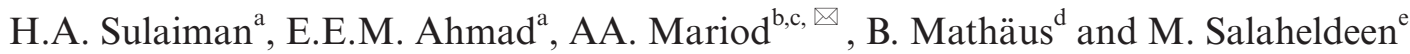 \\ ${ }^{a}$ Department of Chemistry, Sudan University of Science and Technology, Khartoum, Sudan \\ ${ }^{b}$ Department of Biology, College of Science and Arts, University of Jeddah, Alkamil, KSA \\ 'Indigenous Knowledge Center, Ghibaish College of Science and Technology, Ghibaish, Sudan \\ ${ }^{\mathrm{d}}$ Max Rubner-Institute, Department for lipid research, Working Group for Lipid Research, Detmold, Germany \\ ${ }^{\mathrm{e}}$ Department of Chemistry, Faculty of Education, Nile Valley University, Atbara, Sudan \\ ${ }^{\otimes}$ Corresponding author email: basitmariod@yahoo.com; aalnadif@uj.edu.sa
}

Submitted: 15 April 2017; Accepted: 29 September 2017

\begin{abstract}
SUMMARY: The present research work was intended to study the influence of roasting and germination of the kernel seeds of Sudanese Moringa peregrina on the physicochemical characteristics and the oxidative stability of the extracted oil. Roasting was carried out at $180{ }^{\circ} \mathrm{C}$ for 25 minutes, whereas germination was done at ambient conditions in a wet jute bag for 5-7 days. The oil was extracted using n-hexane in a Soxhlet extraction apparatus. The results show that the oil contains $\alpha$-tocopherols $(152 \mathrm{mg} / \mathrm{kg}$ ) and oleic acid (above $70 \%$ ) as the major tocols and fatty acids, respectively. Germination reduced the peroxide value and increased the acid value in a significant way $(\mathrm{p}<0.05)$ whereas the opposite trend was noticed in the case of roasting. It is crucial to note that, with the exception of the acid value of the germinated sample, peroxide and acid values remained below one meq $\mathrm{O}_{2} /$ $\mathrm{Kg}$ of oil and one $\mathrm{mg} \mathrm{KOH} / \mathrm{g}$ of oil, respectively. The oxidative stability of the oil from the roasted sample was increased almost by $80 \%$ compared to the raw one. Roasting of the kernels prior to oil extraction is imperative for improving its oxidation resistance and the physicochemical characteristics.
\end{abstract}

KEYWORDS: Germination; Fatty acids composition; Moringa peregrina; Oxidative stability; Plastochromanol (PC-8); Roasting; Tocols

RESUMEN: Efecto del pretratamiento sobre la composición proximal, características fisicoquímicas y estabilidad del aceite de Moringa peregrina. El presente trabajo de investigación tuvo como objetivo estudiar la influencia de la torrefacción y la germinación de semillas de grano de Moringa peregrina sudanesa sobre las características físicoquímicas y la estabilidad oxidativa del aceite extraido. La torrefacción se llevó a cabo a $180^{\circ} \mathrm{C}$ durante 25 minutos, mientras que la germinación se realizó en condiciones ambientales en una bolsa de yute húmeda durante 5-7 días. El aceite se extrajo utilizando n-hexano en un aparato de extracción Soxhlet. Los resultados han demostrado que el aceite contiene $\alpha$-tocoferoles $(152 \mathrm{mg} / \mathrm{kg}$ ) y ácido oleico (por encima del $70 \%$ ) como tocolos y ácidos grasos mayoritarios, respectivamente. La germinación redujo el valor de peróxido y aumentado la acidez de forma significativa $(\mathrm{p}<0,05)$, mientras que la tendencia opuesta se observó en el caso del tostado. Es importante señalar que, excepto el valor acidez de la muestra germinada, los valores de peróxido y acidez permanecieron por debajo de un meq $\mathrm{O}_{2} / \mathrm{Kg}$ de aceite y un $\mathrm{mg} \mathrm{KOH} / \mathrm{g}$ de aceite, respectivamente. La estabilidad oxidativa del aceite de la muestra tostada incrementó casi un $80 \%$ en comparación con la cruda. La torrefacción de los granos antes de la extracción de aceite es crucial para mejorar su resistencia a la oxidación y las características fisicoquímicas.

PALABRAS CLAVE: Composición de ácidos grasos; Estabilidad oxidative; Germinación; Moringa peregrina, Plastochromanol (PC-8); Tocols; Tostado

ORCID ID: Sulaiman HA http://orcid.org/0000-0001-5462-8037, Ahmad EEM http://orcid.org/0000-0003-1269-1315, Mariod AA http://orcid.org/0000-0003-3237-7948, Mathaus B http://orcid.org/0000-0002-9222-8939, Salaheldeen M http://orcid.org/0000-0002-3375-8139

Citation/Cómo citar este artículo: Sulaiman HA, Ahmad EEM, Mariod AA, Mathäus B, Salaheldeen M. 2107. Effect of pretreatment on the proximate composition, physicochemical characteristics and stability of Moringa peregrina oil. Grasas Aceites 68 (4), e227. http://dx.doi.org/10.3989/gya.0444171

Copyright: (C2017 CSIC. This is an open-access article distributed under the terms of the Creative Commons Attribution (CC-by) Spain 3.0 License. 


\section{INTRODUCTION}

The family Moringaceae encompasses fourteen species that belong to only one genus called Moringa. With some exceptions, they are widely distributed in most of Africa, tropical Asia, Latin America, the Caribbean, parts of North America, and Pacific Islands (Verdcourt, 1986). M. oleifera Lam., extensively studied and most widely known for its nutritional and medicinal applications, has enjoyed special attention owing to its vast distribution and availability (Gopalakrishnan et al., 2016). On the other hand, M. peregrina which has fascinating nutritional and medicinal uses does not receive the same attention due to its limited distribution. It is found in arid and semi-arid countries neighboring the Red Sea, from Somalia and Yemen to Israel and on to Syria. Other distribution areas include Ethiopia, Pakistan, and Iran (van der Vossen and Mkamilo, 2007). In Sudan, El Amin (El Amin, 1990) has reported the distribution of $M$. peregrina in several parts, which include the hills of the Red Sea, Blue Nile, Kordfan, Darfure, and Northern Sudan.

Oil is the main component obtained from the Moringa peregrina seed. It is utilized for cooking as well as in cosmetics and medicine. Some studies have found that the oil has comparable characteristics with olive oil and can be used as a substitute (Tsaknis, 1998; Somali et al., 1984). In addition, a recent study by Salaheldeen et al., (Salaheldeen et al., 2014) has revealed that $M$. peregrina oil is an excellent source of a bio-fuel. In another study, (Abd El Baky and El-Baroty, 2013) the oil was reported to have anticancer and antioxidant properties.

The processing of seeds (roasting, boiling, germination, etc.) prior to oil extraction is well known to have important effects on the quality and properties of the produced oils as well as on the proximate composition of the kernels. Both roasting and germination were extensively applied and studied for many samples and the characteristics of the obtained oils were thoroughly investigated and reported in the literature (Mariod et al., 2012a; Mariod et al., 2012b). To the best of our knowledge this is the first study to report on the effects of roasting and germination of the kernel seeds of $M$. peregrina on the physicochemical characteristics and oxidative stability of the extracted oil. In addition, very limited information about the quality of the oil of $M$. peregrina native to Sudan was noticed in the published literature, so this study will fill the gap and give a better comparison with the other growing environments of M. peregrina.

\section{MATERIALS AND METHODS}

\subsection{Sample collection and pretreatments}

Moringa peregrina seeds were collected from their original growing places (Wadi Alkasinger) in the Northern State of Sudan. The seeds were cleaned from any extraneous materials and dehulled using a hammer. The kernels were stored at $10{ }^{\circ} \mathrm{C}$ before use.

\subsection{Roasting of the kernels}

Roasting was carried out following the method of Mariod et al., (2012b). A KUMTEL electric oven (LX3520 T-INOX, with an adjustable thermostat $80-320^{\circ} \mathrm{C}$, homogeneous heat distribution, and timer function, Turkey) was used for the roasting process at $180{ }^{\circ} \mathrm{C}$ for 25 minutes. The kernels were arranged in a single layer on an aluminium tray, roasted under the specified conditions, allowed to cool to room temperature and then stored at $10{ }^{\circ} \mathrm{C}$.

\subsection{Germination of the seeds}

The germination process of $M$. peregrina seeds was performed following the method of OmowayeTaiwo et al., (2015) with a slight modification. Typically, $2 \mathrm{Kg}$ of $M$. peregrina seeds were thoroughly washed with distilled water, laid uniformly in a wet-jute bag, covered with another wet-jute bag and finally with a thin layer of soil. The contents were kept wet by regular irrigation with water (four to five times a day) under ambient conditions. Germination takes five days to occur and in some cases, six to seven days. The germinated seeds were oven-dried, dehulled and stored at $10{ }^{\circ} \mathrm{C}$ for further analysis.

\subsection{Proximate chemical composition}

Proximate composition (Moisture, ash, protein, and lipids) of the kernels of $M$. peregrina was determined following the standard methods of the Association of Official Analytical Chemists (AOAC) (AOAC, 1990). Triplicate analyses were done for each of the analyzed parameters and the mean as well as the standard deviation were calculated (mean $\pm \mathrm{SD}$ ). Total carbohydrates were determined by difference and the standard deviation was calculated using propagation of error.

\subsection{Determination of physical properties of the oil}

The specific gravity and the refractive index of $M$. peregrina oil were determined based on the standard methods of the Association of Official Analytical Chemists (AOAC) (AOAC, 1990).

\subsection{Determination of viscosity}

The viscosity of the $M$. peregrina oil was measured under ambient conditions using a Thermo Scientific HAAKE viscotester 6 plus. About $40 \mathrm{~mL}$ of the oil sample were placed in a clean-dry glass beaker and the rotor was immersed in the oil. The speed of rotation was set at 200 rounds per min and the viscosity was read directly from the instrument. 
Duplicate measurements were carried out and the mean as well as the standard deviation were calculated (AOCS, 2011).

\subsection{Determination of color}

The color of the $M$. peregrina oil was determined using a Lovibond Tintometer type 4D. A cleaned glass cell was filled with the oil and placed in the Tintometer. The color of the oil was compared with Lovibond glasses of known color and the results were expressed as the sum total of the yellow and red slides $(\mathrm{Y}+\mathrm{R})$ used to match the color of the oil (AOCS, 2011).

\subsection{Determination of chemical properties of the oil}

The acid, peroxide, and saponification values of the oil were studied according to the standard methods of the Association of Official Analytical Chemists (AOAC 1990). In each case triplicate analyses were carried out and the mean and the standard deviation were calculated (mean \pm SD).

\subsection{Fatty acid composition of the oils}

The fatty acids were converted to methyl esters and determined following the ISO standard ISO 5509:2000 (ISO 5509:2000). Each sample was injected into a HP5890 gas chromatograph (Agilent Technologies Sales \& Services GmbH \& Co. KG, Waldbronn, Germany) equipped with a flame ionization detector and a CP-Sil 88 capillary column (100 m long, $0.25 \mathrm{~mm}$ ID, film thickness $0.2 \mu \mathrm{m}$ ). The operational conditions were set as follows: Heated from $155^{\circ} \mathrm{C}$ to $220{ }^{\circ} \mathrm{C}\left(1.5^{\circ} \mathrm{C} / \mathrm{min}\right)$ and held for $10 \mathrm{~min}$ isothermally; injector temperature, $250{ }^{\circ} \mathrm{C}$; detector temperature, $250{ }^{\circ} \mathrm{C}$; carrier gas $36 \mathrm{~cm}^{3} / \mathrm{s}$ nitrogen; split ratio 1:50; detector gas $30 \mathrm{~mL} / \mathrm{min}$ hydrogen; $300 \mathrm{~mL} / \mathrm{min}$ air and $1 \mathrm{~mL} / \mathrm{min}$ nitrogen; manual injection volume less than $1 \mu \mathrm{L}$. The peak areas were computed by the integration software, and percentages of fatty acid methyl esters (FAME) were obtained as weight percent by direct internal normalization.

\subsection{Determination of tocols and plastochromanol contents of the oils}

For the investigation of vitamin-E, a solution of $250 \mathrm{mg}$ of oil in $25 \mathrm{~mL}$ of $\mathrm{n}$-heptane was specifically used for the HPLC. The HPLC investigation was carried out using a Merck-Hitachi low-pressure gradient system, equipped with a L-6000 pump (Merck-Hitachi, Darmstadt, Germany), a MerckHitachi F-1000 fluorescence spectrophotometer (Darmstadt, Germany; detector wavelengths for excitation $295 \mathrm{~nm}$, for emission $330 \mathrm{~nm}$ ), and a ChemStation joining system (Agilent Technologies Deutschland $\mathrm{GmbH}$, Böblingen, Germany). The samples in the measurement of $20 \mu \mathrm{L}$ were injected by a Merck 655-A40 autosampler (Merck-Hitachi, Darmstadt, Germany) onto a diol phase HPLC section $25 \mathrm{~cm} \times 4.6 \mathrm{~mm}$ ID (Merck, Darmstadt, Germany) at a flow rate of $1.3 \mathrm{~mL} / \mathrm{min}$. The portable phase was $99 \mathrm{~mL} \mathrm{n}$-heptane $+1 \mathrm{~mL}$ tert-butyl methyl ether (Balz et al. 1992).

\subsection{Rancimat test}

The oxidative stability of the oil was studied based on the International Standard Organization method (ISO 6886, 2006). The test was conducted on a 743 Rancimat (Metrohm, Herisau, Switzerland) apparatus. The induction period (IP, h) was determined by subjecting the sample ( $3 \mathrm{~g}$ of oil) to the normal operation conditions of the test by heating at $110{ }^{\circ} \mathrm{C}$ and the flow rate of the air was $20 \mathrm{~L} / \mathrm{h}$.

\subsection{Statistical analysis}

Statistical analyses were performed to assess the influence of roasting and germination processes on the characteristics of the kernels as well as the extracted oil of $M$. peregrina. In each case, triplicate measurements/analyses were carried out (a few measurements were taken in duplicate). Analysis of variance (ANOVA) was used to evaluate the significance between the raw and the processed samples using SPSS 20.0. The variant means were separated using least significant difference method (LSD). The level of significance was set at $p<0.05$. In addition, the means and the standard deviations were calculated and reported in Table 1 to 3 .

\section{RESULTS AND DISCUSSION}

\subsection{Proximate composition of $M$. peregrina kernel seeds}

The chemical compositions of raw, roasted, and germinated kernel seeds of Moringa peregrina are given in Table 1. As is obvious from the table, the kernels of the raw sample compose of $2.9 \%$ moisture, $2.60 \%$ ash, $30.16 \%$ protein, $40.80 \%$ fat, and $23.54 \%$ total carbohydrates. The values of moisture and ash of the raw sample fall within the range of the previous studies (Somali et al., 1984; Al-Dabbas et al., 2012; Gharibzahedi et al., 2013). On the other hand, with the exception of the fat content reported by Abd El Baky and El-Baroty (2013), which is in good agreement with the present study $(42.23 \%$ against $40.77 \%$, respectively), the other studies (Somali et al., 1984; Tsaknis, 1998; Al-Dabbas et al., 2012) have reported fairly higher fat contents (greater than 50\%). The protein content, furthermore, was found to be $30.6 \%$, whereas Somali et al., (1984), Gharibzahedi et al., (2013), and Al-Dabbas et al., (2012) reported $22 \%, 23.4 \%$, and $24.1 \%$, respectively. Similarly, the total carbohydrate content is $23.57 \%$, which is also 
somewhat higher than the reported values (Somali et al., 1984; Gharibzahedi et al., 2013). These variations in protein, total carbohydrates, and fat contents could be attributed to the differences in the growing environments and origin of the studied samples. Roasting and germination, on the other hand, did not have significant effects $(p>0.05)$ on fat and total carbohydrate contents of the samples. In contrast, a significant difference $(p<0.05)$ in ash content between raw and germinated samples was noticed. Based on the literature, the increase in the mineral (particularly calcium and magnesium) contents as a result of germination was attributed to the process of soaking and rinsing with tap water, which contains these elements (Bau et al., 1997). Nevertheless, other authors (El-Adawy, 2002; Mariod et al., 2012a) have observed the opposite trend for a germinated sample and explained that loss in minerals because of the leaching process during germination. This inconsistency between the different studies was attributed to variations in germination conditions, seed varieties or cultivars, and analytical methods (Bau et al., 1997; Mariod et al., 2012a). Furthermore, the moisture and the protein contents of the germinated sample showed significant differences $(\mathrm{p}<0.05)$ compared to the raw one. These considerable changes in crude protein and moisture could be due to an alteration of the chemical composition of the kernels during germination as a result of enzymatic degradation or synthesis of the constituents (Bau et al., 1997).

\subsection{Fatty acids composition of M. peregrina oil}

The fatty acids composition of $M$. peregrina oil extracted from raw, roasted and germinated samples was determined by gas chromatography and the results are shown in Table 2. As it is evident from the table, eighteen fatty acids were detected in the oil samples; eight of them (Oleic $>$ palmitic $>$ stearic $>$ cisvaccenic $>$ behenic $>$ arachidic $>$ palmitoleic $>$ gadoleic) stand for $98.02 \%$ of the total fatty acids (only the acids with percentages greater $1 \%$ were considered here). Two of the remaining acids represent $0.75 \%$ (Lignoceric acid) and $0.13 \%$ (Margaric acid) and the remaining six fatty acids are in trace amounts (all accounted for $1 \%$ approx.). The major unsaturated fatty acids (Oleic (70.88\%), cis-vaccenic $(3.57 \%)$, and palmitoleic $(2.22 \%)$ acids) constitute about $76.67 \%$ of the total fatty acids whereas the major saturated fatty acids (Palmitic (8.38\%), stearic $(5.49 \%)$, behenic $(3.08 \%)$, and arachidic $(2.76 \%)$ acids) compose about $19.71 \%$. Compare to the previous studies (Somali et al., 1984; Gharibzahedi, et al., 2013; Tsaknis, 1998; Al-Dabbas et al., 2012), only oleic, palmitic, stearic, palmitoleic, behenic, and arachidic acids represent the commonly reported fatty acids of $M$. peregrina oil. With few exceptions the present study compares well with those studies regarding the previously mentioned fatty acids. In addition, the presence of cis-vaccenic acid $(3.57 \%)$ in $M$. peregrina oil is reported for the first time by the present study. However, linoleic and linolenic acids, which were reported by Somali et al., (1984), Al-Dabbas et al., (2012), and Gharibzahedi et al., (2013) were not detected in the present study (only linoleic acid, $0.8 \%$, in germinated sample). Similar to the present study, Tsaknis (1998) reported the detection of a small amount of linoleic acid $(0.6 \%)$ while linolenic acid was not detected. On the other hand, lignoceric and gadoleic acids, which were found to be $0.75 \%$ and $1.64 \%$ in the present study, were only reported by Al-Dabbas et al., (2012) at $0.45 \%$ and $1.62 \%$, respectively. Furthermore, only germination seems to have a significant $(\mathrm{p}<0.05)$ influence on the fatty acid composition of the extracted oils. Stearic, palmitic, arachidic, and behenic acids were significantly $(\mathrm{p}<$ 0.05 ) decreased whereas gadoleic acid was considerably $(\mathrm{p}<0.05)$ increased as a result of germination (Table 2). Herchi et al., (2015) reported that germination increased the levels of the polyunsaturated fatty acids (Linoleic acid in particular) and decreased the levels of the saturated fatty acids which make the oil prone to oxidation. In a similar manner, the findings of the present study displayed that the percentages of the saturated fatty acids were decreased markedly $(\mathrm{p}<0.05)$ and a minor amount of linoleic acid was detected, $0.80 \%$, for the oil extracted from the germinated sample. Moreover, the level of the gadoleic

TABLE 1. Proximate chemical composition of the kernel seeds of M. peregrina

\begin{tabular}{lccc}
\hline & & Sample, \% (mean \pm SD) & Germinated \\
\cline { 2 - 4 } Parameter & Raw & Roasted & $3.90 \mathrm{c} \pm 0.02$ \\
Moisture & $2.90 \mathrm{a} \pm 0.2$ & $3.32 \mathrm{~b} \pm 0.12$ & $3.91 \mathrm{c} \pm 0.02$ \\
Ash & $2.60 \mathrm{a} \pm 0.08$ & $2.97 \mathrm{~b} \pm 0.01$ & $27.25 \mathrm{~b} \pm 0.44$ \\
Crude protein & $30.16 \mathrm{a} \pm 0.41$ & $29.72 \mathrm{a} \pm 0.43$ & $41.43 \mathrm{a} \pm 1.07$ \\
Crude fat & $40.77 \mathrm{a} \pm 0.11$ & $43.08 \mathrm{a} \pm 1.14$ & $23.49 \pm 1.16$ \\
Total carbohydrates & $23.57 \pm 0.48$ & $20.91 \pm 1.22$ & \\
\hline
\end{tabular}

* Values are means $( \pm \mathrm{SD})$. In case of carbohydrates the standard deviation was calculated using propagation of error.

$* *$ Mean values followed by different letters within a row are significantly $(\mathrm{p}<0.05)$ different $($ Comparison was made between raw and roasted as well as raw and germinated samples only). 
TABLE 2. The fatty acid composition, physical and chemical properties of Moringa peregrina oil extracted from raw and processed samples.

\begin{tabular}{|c|c|c|c|}
\hline \multirow[b]{2}{*}{ Parameter } & \multicolumn{3}{|c|}{ Sample (mean \pm SD) } \\
\hline & Raw & Roasted & Germinated \\
\hline C16:0 & $8.38 \mathrm{a} \pm 0.04$ & $8.20 \mathrm{a} \pm 0.15$ & $7.55 b \pm 0.04$ \\
\hline $\mathrm{C} 16: 1 \Delta 7$ & $0.08 \pm 0.01$ & $0.08 \pm 0.00$ & $0.10 \pm 0.00$ \\
\hline $\mathrm{C} 16: 1 \Delta 9$ & $2.22 \mathrm{a} \pm 0.01$ & $2.04 \mathrm{a} \pm 0.05$ & $2.02 \mathrm{a} \pm 0.01$ \\
\hline $\mathrm{C} 17: 0$ & $0.13 \pm 0.01$ & $0.13 \pm 0.00$ & $0.12 \pm 0.00$ \\
\hline $\mathrm{C} 17: 1$ & $0.07 \pm 0.00$ & $0.07 \pm 0.00$ & $0.06 \pm 0.00$ \\
\hline C18:0 & $5.49 \mathrm{a} \pm 0.01$ & $5.50 \mathrm{a} \pm 0.01$ & $4.55 b \pm 0.11$ \\
\hline $\mathrm{C} 18: 1 \Delta 9$ & $70.88 \mathrm{a} \pm 0.16$ & $71.42 \mathrm{a} \pm 0.02$ & $73.07 a \pm 0.06$ \\
\hline $\mathrm{C} 18: 1 \Delta 11$ & $3.57 \mathrm{a} \pm 0.01$ & $3.46 \mathrm{a} \pm 0.01$ & $3.55 \mathrm{a} \pm 0.01$ \\
\hline $\mathrm{C} 18: 2 \Delta 9,12$ & - & - & $0.80 \pm 0.01$ \\
\hline $\mathrm{C} 18: 3 \Delta 9,12,15$ & $0.02 \pm 0.00$ & $0.02 \pm 0.00$ & $0.05 \pm 0.00$ \\
\hline $\mathrm{C} 20: 0$ & $2.76 \mathrm{a} \pm 0.01$ & $2.68 \mathrm{a} \pm 0.05$ & $2.37 \mathrm{~b} \pm 0.01$ \\
\hline $\mathrm{C} 20: 1$ & $1.64 \mathrm{a} \pm 0.01$ & $1.62 \mathrm{a} \pm 0.02$ & $1.71 \mathrm{~b} \pm 0.02$ \\
\hline $\mathrm{C} 20: 211,14$ & $0.04 \pm 0.00$ & $0.04 \pm 0.01$ & $0.03 \pm 0.00$ \\
\hline $\mathrm{C} 22: 0$ & $3.08 \mathrm{a} \pm 0.04$ & $2.95 \mathrm{a} \pm 0.07$ & $2.71 b \pm 0.04$ \\
\hline $\mathrm{C} 22: 1$ & $0.06 \pm 0.00$ & $0.06 \pm 0.00$ & $0.06 \pm 0.00$ \\
\hline $\mathrm{C} 22: 2$ & $0.05 \pm 0.00$ & $0.04 \pm 0.00$ & $0.05 \pm 0.01$ \\
\hline Specific gravity & $0.9069 \mathrm{a} \pm 0.0020$ & 0.9008 a \pm 0.0030 & $0.9114 \mathrm{a} \pm 0.0002$ \\
\hline Viscosity (cPoise) & $60.5 \mathrm{a} \pm 2.5$ & $50.0 \mathrm{~b} \pm 0.00$ & $70.5 \mathrm{c} \pm 0.50$ \\
\hline RI & $1.464 \mathrm{a} \pm 0.0014$ & $1.464 \mathrm{a} \pm 0.0057$ & $1.465 \mathrm{a} \pm 0.0035$ \\
\hline Color $(\mathrm{Y}+\mathrm{R})$ value & $12.2 \mathrm{Y}+0.1 \mathrm{R}$ & $23.2 \mathrm{Y}+0.3 \mathrm{R}$ & $32.3 \mathrm{Y}+1.3 \mathrm{R}$ \\
\hline $\mathrm{PV}\left(\right.$ meq $\mathrm{O}_{2} / \mathrm{kg}$ of oil) & $0.57 \mathrm{a} \pm 0.04$ & $0.95 b \pm 0.02$ & - \\
\hline AV (mg KOH/g of oil) & $0.68 \mathrm{a} \pm 0.04$ & $0.25 b \pm 0.02$ & $20.03 c \pm 0.13$ \\
\hline $\mathrm{SV}$ (mg KOH/g of oil) & $185.40 \mathrm{a} \pm 5.95$ & $174.18 \mathrm{a} \pm 2.7$ & $180.04 \mathrm{a} \pm 5.36$ \\
\hline
\end{tabular}

* Values are means $( \pm \mathrm{SD})$.

** Mean values followed by different letters within a row are significantly different $(\mathrm{p}<0.05)$ (Comparison was made between row and roasted as well as raw and germinated samples only). In case of fatty acids, statistical analysis was done for major fatty acids only (greater than $1 \%$ ).

acid was noticeably $(\mathrm{p}<0.05)$ increased due to germination while the percentage of the oleic acid showed a slight increase from $70.88 \%$ for the raw sample to $73.07 \%$ for the germinated sample.

\subsection{Physical properties of oil seeds of $M$. peregrina}

Table 2 shows the physical properties of the oil extracted from raw, roasted, and germinated kernels of M. peregrina. As is evident from the table, the oil extracted from the raw sample has a specific gravity of 0.9069 , a refractive index of 1.464 , a viscosity of $60.5 \mathrm{cp}$, and a light yellow color (12.2y, 0.1r). Except the color, which was reported only by Somali et al., (Somali et al., 1984) (24.2y, 0.99r), the other values are in accordance with those reported in the previous studies (Somali et al., 1984; Gharibzahedi et al., 2013; Tsaknis, 1998). In a similar manner, the values of the specific gravity and the refractive index of the oil extracted from roasted and germinated samples remained almost unchanged ( $p>0.05)$. In contrast, the color of the oil significantly changed as a result of roasting and germination processes.

The oil extracted from germinated seeds had a deep brown color (32.3y, 1.3r), whereas the one from roasted kernels had a brown color $(23.2 \mathrm{y}$, $0.3 \mathrm{r}$ ) and finally the oil from raw kernels had a light yellow color $(12.2 \mathrm{y}, 0.1 \mathrm{r})$. The change in the color of the oil due to germination could be due to the increase in the content of chlorophylls and carotenoids, which are synthesized during the different stages of the germination process (Herchi et al., 2015). In the case of roasting, the increase in the intensity of the oil's color may be due to Maillard-type non-enzymatic reactions between reducing sugars and free amino acids or amides during roasting, which lead to the formation of browning substances ( $\mathrm{Ng}$ et al., 2014; Lee et al., 2015). Lee et al., (2015) investigated the Maillard reaction products of perilla oil at different roasting conditions. For an unroasted sample, there were no detectable concentrations 
of these products. However, as the temperature of the roasting increased up to $150{ }^{\circ} \mathrm{C}, 2$-methylpyrazine and 2,5-dimethylpyrazine were detected. Above $180{ }^{\circ} \mathrm{C}$ and up to $240{ }^{\circ} \mathrm{C}$ the presence of furfurylalcohol, guaiacol, and 2-phenylpyridine in addition to the two previously detected compounds were reported. The concentrations of both 2-methylpyrazine and 2,5-dimethylpyrazine increased gradually with increasing roasting temperature and time at first and decreased at higher temperatures whereas the concentrations of the last three compounds were increased with increasing roasting temperature and time. Furthermore, it is also known that $(\mathrm{Ng}$ et al., 2014) the roasting process results in a chemical reaction of phospholipid compounds and this enhances the development of brown pigments. Compared to the oil from the raw sample, the viscosities of the oils from roasted and germinated samples were changed significantly ( $<<0.05)$. Kim et al., (2010) found that the viscosity of vegetable oils depends markedly on the type of the oil (hazelnut, olive, canola, corn, soybean, sunflower, and grape seed oils). A correlation study between the viscosity and the fatty acid composition was carried out to show the dependency of viscosity on the type of oil. The findings revealed that there is no correlation between the viscosity and the total saturation (or unsaturation) of the fatty acids. However, a highly positive correlation was observed between the viscosities of the oils and C18:1 and C18:2 fatty acids. They concluded that these fatty acids seem to have a great contribution to the flow properties of the vegetable oils. With reference to the present study, the variation in the concentration of C18:1 (C18:2 was detected only in the germinated sample) between the raw and the processed samples it was not significant $(p>$ 0.05 ) and did not seem to be the main factor for the observable changes in viscosity. Furthermore, it has been reported in the literature (Zahir et al., 2014) that the viscosity of the vegetable oils increases with increasing saturation and polymerization and decreases with increasing unsaturation. The results of the viscosities for the present study need further consideration.

\subsection{Chemical properties of seed oil of M. peregrina}

Table 2 shows the chemical properties of the oils extracted from raw, roasted, and germinated samples. For the oil extracted from the raw sample, the saponification value agrees well with the findings of Somali et al., (1984), Tsakin et al., (1998), and Gharibzahedi et al., (2013). On the other hand, the acid values of the present study vary significantly in comparison with the previous studies (Somali et al., 1994; Gharibzahedi, et al., 2013). With the exception of the peroxide value reported by Gharibzahedi et al., (2013), which compares favorably with our findings, Somali et al., (1984). reported a quite different value; $2.3 \mathrm{meqO}_{2} / \mathrm{Kg}$ oil against $0.57 \mathrm{meqO}_{2} / \mathrm{Kg}$ oil. In addition, the results revealed that both roasting and germination significantly $(\mathrm{p}<0.05)$ affected the peroxide and the acid values of the extracted oil. The peroxide value of the oil obtained from the roasted sample increased considerably (about 65\% $(\mathrm{p}<0.05))$ compared to the raw one while the acid value decreased significantly (about $63 \%(\mathrm{p}<0.05)$ ), (Table 1). With reference to the peroxide value, most studies (Anjum et al., 2006; Vujasinovic et al., 2012) reported a noticeable increase in the peroxide value with increasing roasting temperature and time whereas a few others (Abou-Gharbia et al., 2000) observed only a marginal decrease compared to unroasted samples. Generally, peroxide value does not correspond to the absolute state of oxidation of oil because hydroperoxides become unstable upon heating and decompose to secondary products (Choe and Min, 2006). Furthermore, roasting decreased the acid value (AV) from $0.68 \mathrm{mg} \mathrm{KOH} / \mathrm{g}$ for the raw sample to $0.25 \mathrm{mg} \mathrm{KOH} / \mathrm{g}$ for the roasted one (p < 0.05 ). Refer to Table 2, it is clear that roasting significantly $(\mathrm{p}<0.05)$ decreased $\alpha$ - and $\gamma$-tocopherols in comparison to the raw sample whereas it slightly increased the content of plastochromanol-8 ((PC$8)$ ). Both tocols and PC-8 are well known for their antioxidant activities, so the considerable decrease in the acid value of the oil from the roasted sample could not be due to the change in the contents of tocols ( $\alpha$ and $\gamma$ ) as they were decreased drastically. This substantial increase in the acid value was possibly due to the increase in PC-8 as well as the pigments; the color of the oil from roasted kernels changed to deep brown compared to oil from the raw one. It may also be due to the increase in the levels of other compounds that have antioxidant activities like total phenolic compounds (Siger et al., 2015). In this respect, Siger et al., (2015) reported a fluctuating trend of the acid value for rapeseed oil extracted after roasting pretreatments of the seeds for varying temperatures $\left(140,160\right.$, and $\left.180{ }^{\circ} \mathrm{C}\right)$ and times $(5,10$, and 15 minutes). Oil from the untreated seeds has an acid value of $0.61 \mathrm{mg} \mathrm{KOH} / \mathrm{g}$ whereas the minimum value for the oil from treated samples was $0.51 \mathrm{mg} \mathrm{KOH} / \mathrm{g}$ and the maximum was $0.68 \mathrm{mg}$ $\mathrm{KOH} / \mathrm{g}$.

On the other hand, germination drastically $(\mathrm{p}<$ 0.05 ) increased the acid value and the free fatty acids from $0.68 \mathrm{mg} \mathrm{KOH} / \mathrm{g}$ and $0.34 \%$ for the raw sample to $20.03 \mathrm{mg} \mathrm{KOH} / \mathrm{g}$ and $10.08 \%$ for the germinated one. The higher percentage of FFA and acid value for the oil extracted from germinated seeds could be due to the initial hydrolysis (lipolysis) of triacylglycerols by lipases, enzymes that catalyze the three-stage hydrolytic cleavage of the fatty acid ester bonds in triacylglycerols (TAGs), ultimately to yield glycerol and free fatty acids (FFA) (Bewley and Black, 1994). 
TABLE 3. Tocopherols, tocotrienols and plastochromanol composition of Moringa peregrina oil extracted from raw and processed kernels

\begin{tabular}{lccc}
\hline & \multicolumn{3}{c}{$\mathbf{m g / 1 0 0 g}$} \\
\cline { 2 - 4 } Tocopherols & Raw & Roasted & Germinated \\
\hline$\alpha-\mathrm{T}$ & $15.2 \mathrm{a} \pm 0.0$ & $13.3 \mathrm{~b} \pm 0.4$ & $16.0 \mathrm{a} \pm 0.4$ \\
$\beta-\mathrm{T}$ & $0.25 \pm 0.07$ & $0.3 \pm 0.0$ & $0.3 \pm 0.0$ \\
$\gamma$-T & $1.55 \mathrm{a} \pm 0.07$ & $1.25 \mathrm{~b} \pm 0.07$ & $1.4 \mathrm{a} \pm 0.0$ \\
$\delta$-T & - & $0.05 \pm 0.07$ & $0.1 \pm 0.0$ \\
PC-8 & $0.55 \mathrm{a} \pm 0.07$ & $0.9 \mathrm{a} \pm 0.0$ & $0.35 \mathrm{a} \pm 0.4$ \\
Tocotrienols & & & \\
$\alpha-\mathrm{T} 3$ & $0.7 \mathrm{a} \pm 0.1$ & $0.4 \mathrm{a} \pm 0.0$ & $0.45 \mathrm{a} \pm 0.07$ \\
$\beta$-T3 & - & - & - \\
$\gamma$-T3 & - & - & $0.05 \pm 0.07$ \\
$\delta$-T3 & - & - & - \\
\hline
\end{tabular}

*Values are means $( \pm S D)$.

** Statistical analysis was performed for $\alpha$ - and $\gamma$-tocopherols as well as PC-8 and $\alpha$-T3. Means followed by different letters within a row are significantly $(\mathrm{p}<0.05)$ different (Comparison was made between raw and roasted as well as raw and germinated samples only).

\subsection{Tocols and plastochromanol-8 contents of $M$. peregrina oil}

The tocopherols and tocotrienols (tocols) as well as plastochromanol-8 contents of $M$. peregrina oil extracted from raw, roasted and germinated samples was determined by high performance liquid chromatography and the results are shown in Table 3 . The results showed that the oil contained $\alpha$-tocopherol as the major constituent of the tocols $(15.2 \mathrm{mg} / 100 \mathrm{~g})$; with $\beta$ - and $\gamma$-tocopherols as well as $\alpha$-tocotrienols present in small quantities (total tocols equal $17 \mathrm{mg} / 100 \mathrm{~g}$ ). Moreover, the oil was found to contain $0.55 \mathrm{mg} / 100 \mathrm{~g}$ plastochromanol. To the best of our knowledge, this is the first study to report on the identity and the quantity of each of the tocols as well as PC-8 in M. peregrina oil, so comparison with the previous studies is not included. However, Abd El Baky and El-Baroty (2013) reported only the total tocopherols using a spectrophotometric method and their results are not quite different from the present study; $20.35 \mathrm{mg} / 100 \mathrm{~g}$ versus $17 \mathrm{mg} / 100 \mathrm{~g}$, respectively. With respect to the oil from processed samples, only roasting changed the contents of $\alpha$ - and $\gamma$-tocopherols in a significant way $(p<0.05)$ while the contents of tocotrienols and PC-8 did not change appreciably $(\mathrm{p}>0.05)$.

\subsection{Oxidative stability of $M$. peregrina oil}

The oxidative stability of $M$. peregrina oil from raw, roasted, and germinated samples was evaluated by a Rancimat method and the induction period (IP) for each sample was determined at $110{ }^{\circ} \mathrm{C}$ and the results were reported as hours (h). The induction periods of the samples were as follows: $47.67 \mathrm{~h}$ raw, $85.95 \mathrm{~h}$ roasted and $49.58 \mathrm{~h}$ germinated. It is clear that both roasting and germination had positive effects on the oxidative stability of the oil. Roasting substantially increased the oxidative stability of $M$. peregrina oil from $47.67 \mathrm{~h}$ to $85.95 \mathrm{~h}$ while germination increased it from $47.67 \mathrm{~h}$ to $49.58 \mathrm{~h}$. The oxidative stability of vegetable oils depends on the fatty acids composition (saturated, unsaturated, number and position of the double bonds, etc.,) as well as the presence and amount of antioxidants (tocols, plastochromanol, pigments, phenolic compounds and others). Vegetable oils having high levels of oleic acid are known to have better resistance to oxidation compared to those containing higher levels of linoleic and linolenic acids (Kamal-Eldin, 2006). In the present study, oleic acid represented more than $70 \%$ of the total fatty acids and linoleic as well as linolenic acids were detected in a minor amount in the case of the germinated sample only $(0.8 \%)$. These findings suggest superior resistance of $M$. peregrina oil to oxidation. In the case of roasting where oxidative stability was significantly enhanced, it is important to mention that roasting significantly $(\mathrm{p}<0.05)$ decreased both $\alpha$ - and $\gamma$-tocopherols which are known for their powerful antioxidant activities. Furthermore, the level of PC- 8 was slightly increased. In conclusion, this great decrease in susceptibility of the $M$. peregrina oil to oxidation as a result of roasting could be due to a number of factors which include the observable change in the levels of the pigments (qualitative basis), the increase in PC-8 and may be due to the increase in the amounts of other constituent like phenolic compounds that have antioxidant properties (Lee et al., 2015; Siger et al., 2015).

\section{CONCLUSIONS}

The results of the present study show that $M$. peregrina seeds are a rich source of oil and protein. The oil contains high levels of unsaturated fatty acids (77\% approx.); oleic acid alone stands for more than $70 \%$. Both roasting and germination have considerable influences on the properties of the kernels and the extracted oil as well as the oxidative stability of the oil. Germination altered the composition of the major saturated fatty acids (stearic, palmitic, behenic, and arachidic acids), the viscosity, the acid value, the peroxide value, and the color of the oil in a significant way $(\mathrm{p}<0.05)$. On the other hand, roasting had significant effects $(\mathrm{p}<0.05)$ on the acid value, the peroxide value, the viscosity, the color, and the $\alpha$ - and $\gamma$-tocopherols. Regarding the oxidative stability of the oil, the roasting process had beneficial effects and substantially improved the resistance of the oil to oxidation.

\section{REFERENCES}

Abd El Baky HH, El-Baroty GS. 2013. Characterization of Egyptian Moringa peregrina seed oil and its bioactivities. Int. J. Manage. Sci. Bus. Res. 2, 98-108. 
Abou-Gharbia HA, Shehata AAY, Shahidi F. 2000. Effect of processing on oxidative stability and lipid classes of sesame oil. Food Res. Int. 33, 331-340. https://doi.org/10.1016/ S0963-9969(00)00052-1

Al-Dabbas MM, Ahmad R, Ajo RY, Abulaila K, Akash M, Al-Ismail K. 2012. Chemical composition and oil components in seeds of Moringa peregrina (Forssk) Fiori. Crop Res. 40, 161-167.

American Oil Chemists' Society (AOCS). 2011. Official methods and recommended practices of the American Oil Chemists' Society, 4th edn. AOCS, Champaign, IL.

Anjum F, Anwar F, Jamil A, Iqbal M. 2006. Microwave roasting effects on the physic-chemical composition and oxidative stability of sunflower seed oil. J. Am. Oil Chem. Soc. 83, 777-784. https://doi.org/10.1007/s11746-006-5014-1

Association of Official Analytical Chemists (AOAC). 1990 Official methods of analysis of the Association of Official Analytical Chemists' $15^{\text {th }}$ Edition. Washington, DC, USA.

Balz, M, Schulte, E, Thier, HP. 1992. Trennung von Tocopherolen und Tocotrienolen durch HPLC. Eur. J. Lipid Sci. Technol. 94, 209-213. http://dx.doi. org/10.1002/lipi.19920940604

Bau H-M, Villaume C, Nicolas J-P, Méjean L. 1997. Effect of germination on chemical composition, biochemical constituent and antinutritional factors of soya bean (Glycine max) seeds. J. Sci. Food Agric. 73, 1-9. https:// doi.org/10.1002/(SICI)1097-0010(199701)73:1<1::AIDJSFA694>3.0. CO;2-B

Bewley JD, Bradford K, Hilhorst H, Nonogaki H. 2013. Seeds: Physiology of Development, Germination and Dormancy. Springer Science, USA, 133-181. https://doi. org/10.1007/978-1-4614-4693-4_4

Choe E, Min DB. 2006. Mechanisms and Factors for Edible Oil Oxidation. Compr. Rev. Food Sci. Food Saf. 5, 169-186. https://doi.org/10.1111/j.1541-4337.2006.00009.x

El Amin HM. 1990. Trees and Shrubs of the Sudan. Ithaca Press, Exeter, UK.

El-Adawy TA. 2002. Nutritional composition and antinutritional factors of chickpeas (Cicer arietinum L.) undergoing different cooking methods and germination. Plant Foods Hum. Nutr. 57, 83-97. https://doi.org/10.1023/A:1013189620528

Gharibzahedi, SMT, Ansarifard I, Sadeghi Hasanabadi Y, Ghahderijani M, Yousefi R. 2013. Physicochemical properties of Moringa peregrina seed and its oil. Qual. Assur. Saf. Crop. 5, 303-309. https://doi.org/10.3920/QAS2012.0172

Gopalakrishnan L, Doriya K, Kumar DS. 2016. Moringa oleifera: A review on nutritive importance and its medicinal application. Food Science and Human Wellness 5, 49-56. https://doi.org/10.1016/j.fshw.2016.04.001

Herchi W, Bahashwan S, Sebei K, Ben Saleh H, Kallel H, Boukhchina S. 2015. Effects of germination on chemical composition and antioxidant activity of flaxseed (Linum usitatissimum L) oil. Grasas Aceites, 66, e057. http://dx.doi. org/10.3989/gya.0463141

ISO 5509:2000. 2000. Animal and Vegetable Fats and OilsPreparation of Methyl Esters of Fatty Acids; International Standard ISO 5509:2000; ISO: Geneva, Switzerland.

ISO 6886. 2006. Animal and vegetable fats and oils. Determination of oxidative stability (accelerated oxidation test).

Kamal-Eldin, A. 2006. Effects fatty acids and tocopherols on the oxidative stability of vegetable oils. Eur. J. Lipid Sci. Technol. 58, 1051-1061. http://dx.doi.org/10.1002/ ejlt.200600090
Kim J, Kim DN, Lee SH, Yoo S-H, Lee S. 2010. Correlation of fatty acid composition of vegetable oils with rheological behavior and oil uptake. J. Food Chem. 118, 398-402. https://doi.org/10.1016/j.foodchem.2009.05.011

Lee S, Lee Y-J, Sung J-S, Shin H-S. 2015. Influence of roasting conditions on the chemical properties and antioxidant activity of perilla oils. J. Korean Soc. App. Biol. Chem. 58, 325-334. http://dx.doi.org/10.1007/s13765-015-0046-6

Mariod AA, Ahmed SY, Abdelwahab SI, Cheng SF, Eltom AM, Yagoub SO, Gouk SW. 2012b. Effects of roasting and boiling on the chemical composition, amino acid and oil stability of safflower seeds. Inter. J. Food Sci. Technol. 47, 1737-1743. http://dx.doi. org/10.1111/j.1365-2621.2012.03028.x

Mariod AA, Edris YA, Cheng SF, Abdelwahab SI. 2012a. Effects of germination periods and conditions on chemical composition, fatty acids and amino acids of two black cumin seeds. Acta Sci. Pol. Technol. Aliment. 11, 401-410.

Ng S, Lasekan O, Muhammad K, Sulaiman R, Hussain N. 2014. Effects of roasting conditions on color development and Fourier transform infrared spectroscopy (FTIRATR) analysis of Malaysian-grown tropical almond nuts (Terminalia catappa L.). Chem. Central J. 8, 55. https://doi. org/10.1186/s13065-014-0055-2

Omowaye-Taiwo OA, Fagbemi TN, Ogunbusola EM, Badejo AA. 2015. Effect of germination and fermentation on the proximate composition and functional properties of full-fat and defatted Cucumeropsis mannii seed flours. $J$. Food Sci. Technol. 52, 5257-5263. https://doi.org/10.1007/ s13197-014-1569-2

Salaheldeen M, Aroua MK, Mariod AA, Cheng SF, Abdelrahman MA. 2014. An evaluation of Moringa peregrina seeds as a source for bio-fuel. Ind. Crops Prod. 61, 49-61. https://doi.org/10.1016/j.indcrop.2014.06.027

Siger A, Kaczmarek A, Rudzińska M. 2015. Antioxidant activity and phytochemical content of cold-pressed rapeseed oil obtained from roasted seeds. Eur. J. Lipid Sci. Technol. 117, 1225-1237. http://dx.doi.org/10.1002/ ejlt. 201400378

Somali MA, Bajneid MA, Al-Fhaimani SS. 1984. Chemical Composition and Characteristics of Moringa peregrina Seeds and Seeds oil. J. Am. Oil. Chem. Soc. 61, 85-86. https://doi.org/10.1007/BF02672051

Tsaknis J. 1998. Characterization of Moringa peregrina Arabia seed oil. Grasas Aceites 49, 170-179. http://dx.doi.org/ 10.3989/gya.1998.v49.i2.717

van der Vossen HAM, Mkamilo GS (Eds.). 2007. Plant Resources of Tropical Africa 14: Vegetable Oils. PROTA, Netherlands, 119-120. ISSN:1877-430x

Verdcourt B. Moringaceae. 1986. In: Polhill RM (Ed.). Flora of Tropical East Africa. CRC Press, 1-2. ISBN 9061913195, 9789061913191

Vujasinovic V, Djilas S, Dimic E, Basic Z, Radocaj O. 2012. The effect of roasting on the chemical composition and oxidative stability of pumpkin oil. Eur. J. Lipid Sci. Technol. 114, 568-574. http://dx.doi.org/10.1002/ ejlt. 201100158

Zahir E, Saeed R, Abdul Hameed M, Yousuf A. 2014. Study of physicochemical properties of edible oil and evaluation of frying oil quality by Fourier Transform-Infrared (FT-IR) Spectroscopy. Arab. J. Chem. (Accesed 06-06-2014). http:// dx.doi.org/10.1016/j.arabjc.2014.05.025 